\title{
BUDAYA PEMBELAJAR DAN PEMIMPIN PEMBELAJAR
}

\author{
Emi Zulaifah
}

Universitas Islam Indonesia

\section{INTISARI}

Tulisan in bermaksud mendiskusikan tentang bagaimana dalam perubahan dunia yang terus menerus organisasi tetap adaptik dan pada saat yang sama terjaga budayanya. Menurut penulis, budaya dan belajar ini memang seringkali dianggapsebagai berada di dua ujung garis. Buda ya df satu sisi merupakan stabilisasi, penyatu, kekuatan penjagapembentuk identitas, serta merupakan tatanan yang membuat hal-hal di dalamnya menjadi terduga dengan baik (predictable). D sisi lain, unu tan perubahan membuat anggota dari sebuah organisasi arau budaya itu harus terus menenus belajar (menjadi perpetual learner) yang seringkali memerlukan pelepasan diri dari apa yang sudah ada, melepaskan diri dari asumsi dasar atau paradigma lama yang telah dimiliki, mengambil jarak dari budaya yang telah dimiliki. Dari sini, ada semacam kekhwatiran bahwa menguatnya mental model atau budaya ihu akan menghambat terjadinya pembelajaran itu. Penulis percaya bahwa adalah mungkin diciptakan sebuah kultur organisasi yang di dalam dirinya terdapat ciri-ciri -pembelajaran, adaptif, inovatif dan seterusnya.

Kata Kuncl: Budaya pembelajar, pemimpin pembelajar, organisasi.

Emi Zulaifah, Jahir 5 Juni 1968, adalah dosen Fakulias Psikologi Universifas Islam Indonesia. Lepas dari bangku kuliah of Fakultas Psikologi UGM i segera meneriuni profesi sebagai wartawan Harian Republika dan sekarang ini berprofesi sebagai dosen. Saat ini sedang menempuh program S-2 df Amerika Serikat.
$\mathbf{K}$ enyataan bahwa kehidupan tel ah dan akan terus menerus mengalami perubahan tidak dapat diingkari. Para filsuf telah sejak lama menyatakan bahwa apa yang tetap di dalam dunia ini adalah perubahan, menggarisbawahi tentang dinamisnya lingkungan yang kita tinggali ini. Sebagai ilustrasi saja, hal-hal yang di masa lalu tampak tidak memungkinkan maka d masa kini bisa dimungkinkan. Sebuah kontak dengan dunia yang begitu luas dan 
dilakukan dalam hitungan detik tidak pernah terbayangkan di masa lalu, kini hal itu telah terjadi di depan mata, di rumah-rumah, di atas meja kerja sehari-hari, karena revolusi informasi yang kini tengah terjadi di pelbagai belahan bumi. Dunia yang untuk mengetahuinya pada masa lalu harus dilayari dalam waktu bertahun-tahun kini dapat ditemukan -meskipun masih secara virtual - hanya dalam hitungan detik. Selanjutnya, akal bud manusia yang terus menerus melakukan rekayasa atas lingkungannya akan selalu memicu dan memacu perubahan-perubahan semacam itu.

Dunia akan menjadi lain, tandas Schein (1992) dalam buku Organizational Cutture and Leadership. Organisasi yang -dalam berbagai tingkatan- banyak insan ikut menjadi bagiannya akan menghadapi berbagai tantangan lingkungan yang terus menerus berubah itu. Organisasi yang berhasil dinyatakan oleh Stoltz (1997) harus mampu menghadapi kendala-kendala dalam lingkungannya menjadi peluang-peluang memajukan diri. Dalam kondisi yang sulit atau adverse, serba berubah itus penting bagi organisasi mengembangkan budaya yang membuatnya terus belajar, sehingga ia harus memiliki daya tahan dalam menghadapi adversity tersebut.

Dalam konteks kecepatan perubahan itulah pengertian tentang organisasi yang memiliki kultur atau burd aya pembelajar serta pemimpin pembelajar itu dimunculkan. Pokok persoalan dalam tinjauan tentang budaya dan pemimpin pembelajar ini adalah: Bagaimana dalam perubahan yang terus menerus itu organisasi menjadi tetap adaptif namun pada saat yang sama terjaga budayanya.

Dua hal - budaya dan belajar - ini memang seringkali dianggap sebagai ber. ada di dua ujung garis. Budaya di satu sisi merupakan stabilisasi, penyatu, kekuatan penjaga pembentuk identitas, serta merupa- kan tatanan yang membuat hal-hal di dalamnya menjadi terduga dengan baik (predictable). Schein (1992) mengatakannya sebagai mental model, Hofstede (1990) menyebutnya sebagai collective programming of the mind, yang pada dasarnya mewakili citra, asumsi, serta kerangka berpikir yang ada pada setiap orang, kelompok, serta lembaga (Senge, 1995). Mental model ini dapat dibaratkan sebagai kaca pigura yang kadang-kadang mengubah penglihatan, akan menentukan apa-apa yang dilihat (baca: menjadi peta kogritif yang seringkali belum tentu akurat). Dengan kata lain ahli sering menyebutnya sebagai paradigma.

Di sisi lain, tuntutan perubahan membuat anggota dari sebuah organisasi atau budaya itu harus terus menerus belajar (menjadi perpetual rearner) yang seringkali memerlukan pelepasan diri dari apa yang sudah ada, melepaskan diri dari asumisi dasar atau paradigma lama yang telah dimiliki, mengambil jarak dari budaya yang telah dimiliki. Dari sini, ada semacam kekhwatiran bahwa menguatrya mental model atau budaya itu akan menghambat terjadinya pembelajaran itu.

Pertanyaan lan jut yang dapat dikemuka. kan di sini, jika budaya dan belajar itu memiliki konsekuensinya masing-masing. bisakah keduanya dipertemukan? Bisakah identitas yang terjaga serta tatanan yang merupakan wujud budaya di satu sisi dan kehendak belajar terus menerus yang merupakan wujud nyata adaptasi Organisasi terhadap lingkungannya di sisi lain, menjadi satu kesatuan yang terbentuk dengan baik dalam organisasi? Dengan kata lain mungkinkah diciptakan sebuah kultur organisasi yang dengan sendirinya pembelajar sehinga di dalam dirinya Organisasi itu memiliki ciri-ciri pembelajaran, adaptif, inovatif dan seterusnya. 


\section{BUDAYA DAN PEMIMPIN PEMBELAJAR}

Lingkungan yang terus berubah, tidak bisa tidak harus dihadapi dengan budaya yang dengan sendirinya pembelajar. Budaya yang pembelajar ini memungkinkan organisasi untuk terus menerus mengevaluasi asumsi-asumsi, mental model, paradigma yang dipakai dalam menjalankan organisasinya.

Dengan ini, maka dibutuhkan pula pemimpin organisasi yang dengan sendirinya juga pembelajar. Pemimpin dalam setting lingkungan yang penuh tantangan itu tadi harus berupaya mengembangkan agar organisainya, menjadi organisasi pembelajar. k harus terus menerus membuat diagnosis terhadap organisasi dan melakukan transformasi yang diperlukan sejalan dengan tuntutan lingkungan. Adalah di tangan pemimpin bahwa asusmsi-asumsi mendasar (mental model/ itu dibentuk, stabil kemudian menjadi budaya dan pada saat yang sama mendorong pembelajaran serta perubahan.

Dalam mempertemukan kedua hal itu, yaitu budaya dan pembelajaran, Schein (1992) - menggunakan dimensi-dimensi dari budaya organisasi- mengidentifikasi karakteristik darl apa yang disebut budaya pembelajaran, serta peran pemimpin dalam memfasilitasi budaya pembelajar. Paparan berikut merupakan dimensi yang dimaksud serta penjelasannya:

1. Hubungan Antara Lingkungan Dan Organisasi:

Budaya pembelajar harus lebih dulu memiliki asumsi bahwa lingkungan tempat organisași hidup itu managable. Organisasi yang percaya bahwa ia harus menerima saja "tempat"/niche yang didapat saat ini, merasa nyaman dan menjadi tergantung kepadanya akan kesulitan menghadapi lingkungan yang serba berubah itu. Semakin cepat lingkungan berubah. kepada pemimpin dituntut agar meyakinkan dan menunjukkan bahwa lingkungan harus dan mungkin dikendalikan.

2. Sifat Aktivitas Manusia

Asumsi inti yang ada pada budaya pembelajar harus memasukkan pandangan bahwa manusia adalah pembelajar dan pernecah masalah yang proaktif. Jika budaya dibangun berdasar asumsi yang fatalistik (penerima yang pasif) pembelajaran itu makin sulit dimuncuikan ketika tingkat perubahan makin cepat.

Pemimpin yang pembelajar, karena itu, juga harus menunjukkan keyakinan bahwa penyelesaian masalah secara aktif akan membawa kita pada proses pembelajaran, sehingga ia memberikan cont oh serupa pada anggotanya. Dalam pengertian ini, belajar tidak harus sampai pada suatu penyelesaian yang tuntas, namun proses belajar itu harus menjadi bagian dari budaya itu.

3. Penghayatan akan realitas dan kebenaran

Penyelesaian terhadap suatu masalah dalam organisasi harus diambil dari pencarian yang sifatnya pragmatis. Kebenaran bisa diperoleh dari mana saja. Asusmi yang harus dihindari adalah bahwa "truth"atau kebenaran itu hanya berasal dari satu sumber dan satu metode saja.

Hal ini mengindikasikan perlunya pendekatan ilmiah dalam beberapa hal, dan mungkin pendekatan berdasarkan pengalaman serta dengan oksperimentasi (baca uj coba) sehingga dapat ditemukan kesalahan-kesalahan tindakan dari situ. Prinsip bahwa "No one will be expert enough to find the answer"harus menjadi pegangan. 
Bagi pemimpin hal ini bisa jadi memberatkan, mungkin karena peran yang dibawa, secara otomatis ia diharapkan tahu jawaban atas berbagai persoalan. Karena itu diperlukan keterbukaan dalam hal kekurangpengalaman dan keahlian dalam dirinya.

4. Sifat Dasar Manusia

Manusia pada dasarnya baik dan bisa berubah. Belajar mengimplikasikan pertahanan dan peningkatan. Jika hal ini dimulal dengan pandangan buruk tentang manusia; seperti malas, tidak peduli pada organisasi atau hal-hal $d$ luar dirinya, ia akan menciptakan semacam self fulfilling prophecy, sebagai pembuktian bagi asumsinya itu. Lebih jauh, dalam lingkungan yang menuntut keterampilan serta pengetahuan yang sangat beragam, maka tak pelak lagi asumsi positif itu yang harus dikenakan karena dibutuhkan mutual trust atau saling percaya dalam organisasi tersebut.

5. Penghayatan Akan Hubungan Antar Manusia

Dimensi ini pada dasamya berkaitan dengan orientasi hubungan antar manusia dalam organisasi yang cenderung pada orientasi Kelompok (kolektif) atau individualis; Jika kreativitas dan inovasi akan dimunculkan maka kultur individualisme akan menumbuhkembangkan hal ini. Jika yang dibutuhkan dalam pembelajaran itu adalah penyelesaian persoalan yang sifatnya interdependen serta kompleks maka orientasi kelompok akan lebih menguntungkan. Intinya pembelajaran itu tidak lalu menuntut bahwa organisasi harus memilih salah satu ekstrim, namun keduanya harus dikenakan sesuai lingkungan masingmasing.
Dalam hal asumsi otoritas, apakah harus partisipatif atau otoriter/ paternalistik, pilihan bagi budaya pembelajar juga tidak mudah, tergantung pada keputusan yang akan diam bil. Jika keputusan itu mudah dikomunikasikan dan dipahami maka sistem yang otoriter akan lebih efektif. Jika solusinya kompleks dan menuntut kerja sama antar elemen, maka sistem partisipatif akan lebih menguntungkan.

\section{Penghayatan atas Waktu}

Orientasi waktu yang optimal bagi pembelajaran adalah d tengah-tengah antara orientasi jangka panjang (far future) dan jangka dekat (near future). Organisasi harus mampu berpikir yang cukup jauh untuk bisa menilai konsekuensi suatu kebijakan secara sistemik. Namun di sisi lain organisasi juga harus mampu membayangkan keadaan di jangka yang dekat untuk menilai apakah sebuah penyelesaian akan bisa berjalan. Asumsi "hidup di masa talu atau saat ini" menjadi kurang kuat jika dihadapkan pada lingkungan yang sangat dinamis. Sebuah organisasi yang akan mengambil satu kebijakan, penting untuk meletakkan keputusan tersebut dalam kerangka waktu menengah ini.

\section{Informasi dan komunikasi}

Budaya pembelajar harus menyadari bahwa dimensi ini memiliki makna sangat penting bagi organisasi, sehingga harus menciptakan komunikasi yang multi chamel yang memungkinkan satu sama lain berhubungan terutama dalam memperoleh task relevant information. Komunikasi yang memiliki berbagai saluran ini akan memungkinkan pimpinan dan anggota berkomunikasi dengan baik, lebih dapat 
diakses sehingga alur informasi menjadi lebih lancar dan datang dari berbagai arah.

Dal am kemajuan teknologi informasi, pimpinan yang sulit dijangkau yang seringkali muncul dalam birokrasi, sudah bukan jamannya lagi, karena alur komunikasi memang dengan sendirinya menuntut mereka untuk fleksibel dan menjangkau berbagai lapisan.

\section{Uniformity dan Diversity}

(Keseragaman dan Keragaman)

Organisasi yang memiliki keragaman akan lebih siap dalam menghadápi lingkungannya yang dinamis karena memiliki resource yang diperlukan. Diversitas akan menciptakan subkultur dan subkultur itu akan menjadi penting bagi adanya "belajar" dan inovasi. Oleh karena itu pemimpin yang pembelajar harus menstimulasi keragaman baik pada level individual maupun sub kelompok:

\section{Task VS Relationship Orientation}

Kedua orientasi ini sesungguhnya penting bagi pembelajaran. Dalam lingkungan yang stabil orientasi tugas akan dirasa tepat, dalam lingkungan yang kompleks dan dinamis, orientasi hubungan demi mencapai sating percaya menjadi penting.

to. Pola berpikir linear Vs sistemik

Dalam lingkungan yang kompleks dan saling tergantung, Kemampuan untuk berpikir secara sistemik, menganalisa berbagai kekuatan serta saling hubungan menjadi tuntutan yang tak bisa dihindari. Ini berarti ada keharusan meninggalkan pola pikir linear dan mengembangkan pola berpikir (mental model) yang lebih kompleks.
Kecenderungannya orang melihat persoalan sebagai terpisah dari persoalan lainnya, lepas dari konteksnya, sehingga ketika mengambil pemecahan pun sifatnya setengah-setengah. lbaratnya sakit, cara-cara ini hanyalah mengobati gejala tan pa mencari dengan dalam sumber-sumber dari penyakit tersebut. Cara melihat persoalan yang cenderung parsial ini tidak lagi tepat di dalam organisai yang kompleks, melibatkan ketergantungan antar sału bagian dengan bagian lain dan mungkin antar wilayah tertentu dengan wilayah lain.

\section{PEMIMPIN PEMBELAJAF}

Dari tuntutan hadirnya budaya pembelajar, layak dilanjutkan diskusi tersebut dengan pertanyaan "kira-kira bagaimana model pemimpin yang akan mampu menumbuhkembangkan budaya seperti itu." Pemimpin, tegas Schein harus dengan sendirinya seorang "perpetual learner" atau pembelajar yang terus menerus dan tak kenal lelah. Untuk ini ada tuntutan bahwa pemimpin haruslah:

1. Perseptif dan insight it

ud Pemimpin pembelajar harus perseptif atau tanggap terhadap persoalan, caracara pandang yang dipakai serta penyelesaian persoalan yang diaplikasikan dalam organisasinya. Sikap ini juga harus selalu ia tunjukkan pada anggotaanggotanya.

Selain itu ia juga harus insightful dalam arti bahwa dalam menghadapi perubahan kondisi perusahaan pemimpin harus mengetahui apa masalahnya melalui pemahamannya sendiri, serta mampu memahami budaya yang ada dan unsur-unsur yang tidak berfungsi. Untuk mampu melihat kenyataan dalam budaya organisasinya itu tidaklah mudah 
karena harus mampu menerima kelemahan-kelemahan yang ada dalam organisasi (serta mungkin dirinya) serta keterbatasan kemampuannya.

Sebagai bagian utama dari perubahan budaya itu pemimpin dituntut memiliki objektifitas yang tinggi ketika berhadapan dengan diri dan organisasinya. Hal ini dapat dimunculkan antara lain melalui berbagai pengalaman mengenai pekejiaan yang betóda serta memasuki setting budaya yang beragam. Seperti halnya dalam konseling, individu dibantu untuk bisa berpikir secara obyektif tentang diri mereka. Karena itu konsultan dapat membantu pemimpin untuk menyadari dirinya sendiri apa yang sedang terjadi dan apa yang akan dilakukan. Konsultan dapat juga berperan sebagai terapis budaya', membantu pemimpin mengetahui budaya yang ada dan bagianbagian mana yang menguntungkan dan merugikan.

\section{Motivasi}

Pemimpin pernbelajar tidak hanya perlu memahami dinamika kebudayaan tetapi juga ketrampilan untuk ikut terlibat (campur tangan) dalam proses budaya tersebut. Untuk mengubah beberapa unsur budaya, pemimpin harus mampu membongkar organisasi mereka sendiri. Proses ini seringkali sangat berat karena melibatkan kesediaan untuk menolak praktek-praktek atau cara-cara yang telah mapan (a tau telah dianggap benar). la harus mampu mengatakan bahwa organisasinya tidak dalam kondisi baik dan menyampaikannya pada anggotaanggotanya. Hal ini menuntut kesanggupan pemimpin untuk mencurahkan waktu dan dirinya bagi organisasi yang menjadi tanggung jawabnya, mengkomunikasikan dedikasi serta komitmen pada kelompoknya, di luar kepentingan-kepentingan pribadinya.

\section{Kekuatan emosi}

Pemimpin harus memiliki kekuatan emosional untuk mengatasi (baca: menenangkan) kecemasan yang menyertai perubahan dan tetap suportif dalam melewati masa transisi walaupun ada anggota yang menolaknya. Pemimpin biasanya menjadi target kemarahan dan kritik karena dialah yang akan memberi tantangan pertama terhadap hal-hal yang sudah dianggap wajar dalam sebuah budaya.

4. Mampu mengubah asumsi budaya

Jika suatu asumsi dihilangkan, maka harus didefinisikan ulang ke bentuk yang lain, dan ini merupakan beban pemimpin. Dengan kata lain, pemimpin harus mempunyai kemampuan untuk mempengaruhi redefinisi kognitif dengan mengutarakan pikiran dan menjual visi dan konsepbaru. Pemimpin haus mampu membawa ke permukaan, melihat kembali dan mengubah asumsi-asumsi dasar yang dipakai kelompoknya.

5. Mampu meciptakan Keterlibatan dan Partisipasi

Dalam perubahan budaya itu pemimpin dituntut tidak hanya menjadi orang yang ada di barisan paling depan (seperti temyatakan dalam syarat-syarat sebelumnya), namun pada saat yang sama la harus mampu mendengarkan, terlibat secara emosional dalam upaya kelompok mencapai pemahaman baru terhadap dilema dalam organisasinya, serta tulus berpartisipasi dalam upayanya untuk belajar dan berubah. Para pemimpin sosial, pemuka agama, pemimpin pergerakan mungkin dapat mengandalkan kharisma pnibadi mereka 
dan membuat para pengikutnya melakukan apa yang dia inginkan. Namun, dalam organisasi pemimpin harus bekerja dengan, kelompoknya yang ada pada saat itu, karena la tergantung pada anggota kelompok untuk mencapai misi organisasi. Pemimpin harus mengetahui bahwa redefinisi kognitif hanya bisa terjadi dan berpengaruh pada pikiran para anggota jika mereka mau terlibat secara aktif dalam proses. Seluruh organisasi harus mencapai beberapa tingkat pemahaman dan mengembangkan motivasi untuk berubah sebelum perubahan yang nyata terjadi, dan pemimpin harus menciptakan keikutsertaan tersebut.

Kemampuan untuk melibatkan orang lain dan mendengarkan mereka, dapat menghindarkan pemimpin dari kesalahan mengubah hal-hal yang seharusnya tidak perlu diubah. Ketika pemimpin berasal dari luar organisasi, hal ini menjadi luar biasa penting karena kemungkinan beberapa asumsinya dalam menjalankan organisasi tidak sejalan dengan asumsiasumsi organisasi itu sendiri sehingga akan berpengaruh bag sukses organisasi.

Semakin cepat perubahan terjadi semakin pemimpin dituntut untuk menumbuhkan partisipasi, karena proses pembelajaran itu harus dimiliki tiap-tiap anggotanya.

6. Mampu mempelajari budaya baru

Seorang pemimpin yang baru masuk dalam perusahaan baru, harus mengetahui dan mungkin mengubah budaya yang ada. Berkaitan mandat yang di terimanya ia harus belajar apa yang penting dari budaya yang ada. Dari ber. bagai penelitiannya, Schein mendapati bahwa seorang pemimpin bisa masuk ke dalam budaya organisasi dengan lebih mudah bila mereka tetap berada dalam industri yang sama. Perpindahan pernimpin karena itu sebaiknya dilakukan dengan mempertimbangkan kesamaan tersebut untuk mempermudah terjadinya pembelajaran dalam budaya barunya.

\section{PENELITIAN DAN PENGUKURAN}

Persoalan utama dalam telaah budaya adalah bagaimana mengujinya secara empiris (Sylvester, Anderson dan Patterson, 1999). Ahli telah mengupayakan berbagai cara mengungkap budaya sampai dengan tingkat asumsi dasar yang hid up dalam satu organisasi. Dalam kerangka penelitian budaya ini pula upaya mengungkap budaya pembelajar itu tadi diletakkan.

Schein (1992) menawarkan pendekatanpendekatan yang sifatnya kualitatif, sementara Hofstede telah mencoba menggunakan kuantifikasi. Dalam pandangan Schein pengungkapan budaya secara "paper based" dengan melihat respon orang-orang di dalamnya, baru mampu mengungkap tataran norma dan iklim. Teknik-teknik lain seperti observasi dan interview dipandang mampu mengungkap asumsi dasar yang dianut sebagain besar anggota (Sylvester dkk, 1999).

Dalam kaitan ini Schein (1992) juga mencatat bahwa tidak menjadi suatu keharusan bahwa seluruh dimensi budaya itu diungkap saat praktisi atau peneliti berkeinginan melakukan asesmen. Alasannya, tidak seluruh persoalan yang menyangkut seluruh dimensi budaya itu muncul dalam sebuah organișasi, sangat mungkin (diduga yang sering terjadi memang seperti ini) bahwa sebuah organisasi hanya memiliki persoalan-persoalan berkaitan dengan dimensi tertentu saja, oleh karena itu absah kiranya bila peneliti atau praktissi akan melihat hanya beberapa dimensi saja.

Dalam pengamatan penulis, dari berbagi telaah budaya itu, penjelasan yang diberikan 
ahli lebih sering sangat beragam. Oleh karena itu model-model pengukuran yang dikembangkan pun beragam dengan argumentasi masing-masing. Bila pendekatan kualitatif sangat disarankan Schein, bisa jadi hal itu tak lepas dari latar belakang kompetensinya sebagai seorang ahli d bidang klin is yang kemudian berpindah ke telaah organisasi.

Sementara itu apa yang dilakukan Sylvester, dkk, (1999) merupakan upaya memetakan budaya melalui teori atribusi internal. Teknik penelitian yang dilakukan adalah dengan mencatat hai-hal yang terungkapkan secara lisan dalam observasi dan wawancara dengan anggapan bahwa apa yang dinyatakan itu merupakan wujud dari mental model atau asumsi dasar yang dianut. Hofstede juga bergerak lebih jauh dengan survey questionairenya, sementara Cooke dkk (tt) telah mengembangkan apa yang disebut $\mathrm{OCl}_{\text {, atau }}$ Organizational Culture Inventory dengan konsep yang secara sekilas lebh mengungkap norma dan harapan orang-orang dalam sebuah organisasi, dan bila dilihat dengan kaca mata Schein lebih mengungkap iklim organisasi daripada asumsi dasar itu sendiri.

Dari sini tampak bahwa telaah budaya memang belum selesai. Seperti apa yang ditandaskan Schein, bahkan pembagian dimensi yang ada pun tidak berarti berhenti sampai dengan sepuluh dimensi itu. Namun sejauh ini ke sepuluh dimensi itulah yang berdasar pengamatannya dianggap mewakili realitas budaya itu tadi.

Selanjutnya, menutup uraian singkat ini. layak kiranya mengutip pendapat Herbert Simon bahwa ada keterbatasan dalam upaya manusia menjelaskan persoalan d sekitamya. Hal yang ia sebut sebagai bounded rationalihitu akhirnya akan mengantarkan manusia pada titik "penjelasan yang memadai" saja tidak akan ada penjelasan yang sangat sempurna. Apa yang kita upayakan dalam menjelaskan realitas dan persoalan hanya akan sampai pada tataran go enough dengan kekhasan konteks masing-masing. tidak akan sampai pada tataran seratus persen tepat Oleh karena itu, prinsip bahwa selalu ada ruang bagi peningkatan (there is aways a room for improvemem) kiranyajuga tepat dikenakan pada telaah tentang budaya pembelajaran hingga sejauh ini. $\sqsupset$

\section{DAFTAR PUSTAKA}

Cooke, R.A. t.t Behavioral Norms and Expectation, dalam Organizational Cullure inventory, Level $V$, Leader's Manual. Human Synergistic.

Schein, E. H. 1992. Organizational Culture And Leadership, Second edition. San Fransisco: Jossey - Bass Publishers:

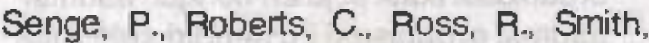
B.J., and Kleiner, A 1994. The Fith Discipline Fieldbook, Strategies and Tools for Building a learning Organization. London: Nicholas Brealy Publishing.

Sylvester. J, Anderson N.R., Paterson F. 1999. Organizational Culure Change: An Intergroup Attributional Analysis, Journal of Occupational and Organizational Psychology, British Psychological Society, Vol 72, hal 1-23.

Stoltz, P.G. 1997. Adversity Quotient: Turning Obstacles into Opportunities. New York: John Wiley and Sons, inc. 